удК 616.89-008

\title{
АНААИЗ ДИНАМИКИ ДЕПРЕССИВНОЙ СИМПТОМАТИКИ И СУИЦИДАМЬНЫХ ИДЕЙ ВО ВРЕМЯ ПАНДЕМИИ COVID-19 В РОССИИ
}

\author{
Т.И. Медведева, С.Н. Ениколопов, О.М. Бойко, О.Ю. Воронииова \\ ФГБНУ „Научный центр психического здоровья», г. Москва, Россия

\begin{abstract}
THE DYNAMICS OF DEPRESSIVE SYMPTOMS AND SUICIDAL IDEATION DURING THE COVID-19 PANDEMIC IN RUSSIA
\end{abstract}

T.I. Medvedeva, S.N. Enikolopov,

Mental Health Research Centre, Moscow, Russia

O.M. Boyko, O.Yu. Vorontsova

Информация об авторах:

Медведева Татьяна Игоревна - клинический психолог (SPIN-код: 6406-4368; Researcher ID: C-2974-2016; ORCID iD: 0000-0002-6012-2152). Место работы и должность: научный сотрудник отдела клинической психологии ФГБНУ "Научный центр психического здоровья». Адрес: Россия, 115522, г. Москва, Каширское шоссе, 34. Эмектронный адрес: medvedeva.ti@gmail.com

Ениколопов Сергей Николаевич - кандидат психологических наук, профессор (SPIN-код: 6911-9855; Researcher ID: C-2922-2016; ORCID iD: 0000-0002-7899-424X). Место работы и должность: заведующий отдемом клинической психологии ФГБНУ “Научный центр психического здоровья». Адрес: Россия, 115522, г. Москва, Каширское шоссе, 34. Электронный адрес: enikolopov@mail.ru

Бойко Омьга Михайловна - клинический психолог (SPIN-код: 1594-1502; ORCID iD: 0000-0003-2895-807X). Место работы и должность: научный сотрудник отдела клинической психологии ФГБНУ „Научный центр психического здоровья". Адрес: Россия, 115522, г. Москва, Каширское шоссе, 34. Электронный адрес: olga.m.boyko@gmail.com

Воронцова Оксана Юрьевна - клинический психолог (SPIN-код: 3767-5067; Researcher ID: O-4843-2018; ORCID: 0000-0001-5698-676X). Место работы и должность: научный сотрудник отдела клинической психомогии ФГБНУ "Научный центр психического здоровья". Адрес: Россия, 115522, г. Москва, Каширское шоссе, 34. Эмектронный адрес: okvorontsova@inbox.ru

Information about the authors:

Medvedeva Tatiana I. - clinical psychologist (SPIN-code: 6406-4368; Researcher ID: C-2974-2016; ORCID iD: 00000002-6012-2152). Place of work and position: research fellow at the clinical psychology department, Mental Health Research Centre. Address: Russia, 115522, Moscow, 34 Kashirskoye highway. Email: medvedeva.ti@gmail.com

Enikolopov Sergey N. - PhD, Professor (SPIN-code: 6911-9855; Researcher ID: C-2922-2016; ORCID iD: 0000-00027899-424X). Place of work and position: Head of clinical psychology Department Mental Health Research Centre. Address: Russia, 115522, Moscow, 34 Kashirskoye highway. Email: enikolopov@mail.ru

Boyko Olga M. - clinical psychologist (SPIN-code: 1594-1502; ORCID iD: 0000-0003-2895-807X). Place of work and position: research fellow at the clinical psychology department, Mental Health Research Centre. Address: Russia, 115522, Moscow, 34 Kashirskoye highway. Email: olga.m.boyko@gmail.com

Vorontsova Oxana Yu. - clinical psychologist (SPIN-code: 3767-5067; Researcher ID: O-4843-2018; ORCID: 00000001-5698-676X). Place of work and position: research fellow at the clinical psychology department, Mental Health Research Centre. Address: Russia, 115522, Moscow, 34 Kashirskoye highway. Email: okvorontsova@inbox.ru

Пандемии COVID-19 может иметь серьёзные последствия для психического здоровья, среди которых рост психопатологической симптоматики, в том числе суицидальных идей и актов аутоагрессии. В нашем исследовании депрессивная симптоматика и суицидальность рассматривались как две характеристики, на которые во время пандемии могут оказывать влияние разные факторы. Цель исследован ия: анализ роста депрессивной симптоматики и суицидальных идей во время пандемии COVID-19 в России. Материалы и методы. Материалом для исследования стали данные анонимного интернет опроса, проведённого с 22 марта по 22 июня 2020 года, опрос включал информацию о социодемографических показателях и вопросы о том, как респондент оценивает своё состояние во время пандемии, среди них вопрос о том, беспокоили ли его последнее время мысли о том о том, чтобы покончить с собой. Использовались опросники: Симптоматический опросник SCL90-R (Simptom Check List-90-Revised), Опросник COРЕ. Статистическая обработка материалов проводилась с помощью пакета программ SPSS. Результаты. Получено 908 ответов. Анализ показал статистически значимую положительную корреляцию между выраженностью суицидальных мыслей и депрессивной симптоматикой в SCL-90R (коэффициент Спирмена 0,$450 ; \mathrm{p}<0,001$ ). Анализ показал статистически значимый тренд роста депрессивной симптоматики по мере развития пандемии (критерий Джонкхиера-Tерпстра, Std. J-Tstat. =2,51, 
p=0,012), и увеличение частоты суицидальных мыслей, которые выражены «сильно» и «очень сильно» в последний период времени (Fisher's Exact Test 5,92; p=0,046). Корреляционный анализ показал, что выраженность депрессии выше у женщин и более молодых респондентов, статистически значимо связана с текущей ситуацией пандемии: растёт с появлением вируса в городе, с появлением заболевших среди знакомых, с увеличением страхов заболеть и умереть, коррелирует с наличием различных соматических заболеваний, и с количеством используемых способов защиты от заражения. Выраженность суицидальных идей не связана с опасностью заражения, появлением больных в окружении, страхами за себя и близких, но связана с более высокой готовностью к риску, выше у более молодых и у мужчин. При этом выраженность депрессивной симптоматики связана с более высоким уровнем таких копинг стратегий как использования эмоциональной социальной и инструментальной поддержки. При росте мыслей о суициде снижается принятие и планирование. Выводы. Рост депрессивной симптоматики и суицидальных мыслей обусловлены разными факторами. Рост депрессивной симптоматики связан с различными страхами и опосредован неконструктивными способами совладания со стрессом. Однако присутствуют и конструктивные копинги - поиск поддержки. Выраженность мыслей о суициде растёт на фоне пандемии COVID-19, и связана с высоким уровнем стресса, который не объясняется «объективной» угрозой заражения и страхами за свою жизнь и жизнь близких, а переживается ими как «неопределённая» тревога, вероятно связанная с мерами противодействия пандемии - ограничениями социального взаимодействия, одиночеством, неопределённостью. Увеличение показателей депрессивной симптоматики связано с ориентацией на «другого» человека, а выраженность суицидальных идей никак с этим не связана.

Ключевые слова: COVID-19, SARS-COV-2, депрессия, суицидальные идеи, копинг стратегии

Пандемия COVID-19 может иметь серьёзные последствия для психического здоровья [1,2].

Рост психопатологической симптоматики. В настоящее время появляется всё больше данных о нарастании симптомов дистресса в течение и после карантина. Так, C. Wang c коллегами обнаружили, что $53,8 \%$ опрошенных, проводивших 20-24 часа дома каждый день во время вспышки COVID19 в Китае, считают, что их психологическое состояние серьезно ухудшилось [3]. Рост тревожных расстройств, депрессивной симптоматики и сообщений о снижении качества сна подтверждается и другими интернет-опросами китайских учёных [4]. Исследования, проведённые в Италии, Дании, Испании и России также продемонстрировали высокие уровни стресса, тревожной и депрессивной симптоматики $[5,6,7$, 8], показали ухудшение психического здоровья населения вследствие социальной изоляции [9]. Снижение уровня психологического благополучия наряду с повышением уровней тревожной и депрессивной симптоматики по сравнению с показателями до пандемии COVID-19 выявлено и метаанализом уже опубликованных данных по психологическим последствиям пандемии COVID-19 [10].

Самоубийства и акты аутоагрессии могут стать серьёзной проблемой по мере распространения пандемии и иметь более долгосрочные последствия для населения в целом [11], для экономики и особенно для уязвимых групп. Люди с психическими расстройствами могут испытывать ухудшение симптомов, а у других могут развиваться новые проблемы с психическим здоровьем, такие как депрессия, тревога и посттравматический стресс (все это связано с повышенным риском суицида). Риск суицида может возрасти из-за стигмы по отношению к людям с COVID-19 и их семьям. Также потеря работы и финансовые факторы стресса - общепризнанные факторы риска самоубийства [12].

Помимо страха заражения, болезни и смерти себя и близких, пандемия COVID-19 и способы борьбы с ней создают также важные внешние условия, существенно повы-
The pandemic of COVID-19 can have serious implications for mental health $[1,2]$.

The increase in psychopathological symptoms. Nowadays, there is growing evidence of increased symptoms of distress during and after the quarantine. Thus, C. Wang et al. found, that $53.8 \%$ of the respondents, who spent 20-24 hours at home every day during the COVID-19 outbreak in China, believe that their psychological state deteriorated significantly [3]. The increase in anxiety disorders, depressive symptoms, and reports on loss of quality of sleep are also confirmed with other internet surveys by the Chinese authors [4]. Studies conducted in Italy, Denmark, Spain, and Russia also showed high levels of stress, anxiety and depressive symptoms $[5,6,7,8]$, deterioration of mental health in the population as a result of social isolation [9]. The decline in the levels of psychological well-being, along with the increased levels of anxiety and depressive symptoms, in comparison with the indices before the COVID-19 pandemic, is confirmed with meta-analysis of the published data on psychological consequences of the COVID-19 pandemic [10].

Suicide and autoaggressive acts may become a serious problem with the spread of pandemic and bear more long-term implications for the general population [11], for economics, and especially for the vulnerable groups. 
шающие суицидальный риск. Это резко возросший уровень неопределённости во всех сферах жизни, что часто переносится тяжелее, чем уже имеющаяся уверенность в наступлении плохого варианта [13], и увеличивает суицидальный риск не только у людей с уже имеющимся психиатрическим диагнозом, но и у людей со сниженной стрессоустойчивостью [14]. Люди с низкой толерантностью к неопределённости испытывают высокий уровень стресса. Снижение толерантности к неопределённости усиливает суицидогенное действие других факторов [15]. Так, например, показано, что снижение толерантности к неопределённости увеличивает суицидальность в морально травмирующих ситуациях у ветеранов боевых действий [16]. Кроме того, низкая толерантность к неопределённости положительно коррелирует с ощущением безнадёжности [17], которое также является одним из важных суицидогенных факторов.

Одновременно с этим, значимым суицидогенным фактором является повышенная чувствительность к имеющимся ограничениям. Его можно описать как невозможность принять имеющиеся или возникшие ограничения, которые не совпадают с внутренним представлением человека о том, как должно быть [18].

Неблагоприятные последствия пандемии, в том числе суицидальный риск, могут усугубляться влиянием самоизоляции и физическим дистанцированием $[14,19]$. Э. Дюркгейм подчеркивал, что социальные связи являются критическим фактором эмоционального здоровья [20]. Исследования показывают, что социальная изоляция (например, проживание в одиночестве) и субъективное ощущение одиночества связаны с суицидальными идеями и поведением [14, 21, 22, 23].

Масштаб пандемии COVID-19 настолько огромен, что трудно выделить событие в предыдущие годы, сопоставимое по своим последствиям. Эпидемия испанского гриппа была связана с увеличением смертности в результате самоубийств 1918-1919 годах [24], которые объясняли нарушением социальных связей во время эпидемии и вызванными ею страхами. Во время вспышки тяжелого острого респираторного синдрома в Гонконге в 2003 г. наблюдался значительный рост числа самоубийств среди людей в возрасте 65 лет и старше [25]. Исследования показывают, что это увеличение может быть связано как со страхом заразиться болезнью, так и со страхом быть бременем для семьи и социальной изоляцией.

Рост суицидальных идей во время пандемии COVID-19 уже выявлен в ряде исследований [26]. Реальные 68 случаев суицида в Индии во время пандемии [27] анализируются с учётом таких факторов как страх заражения, финансовые потери, одиночество, социальная изоляция, принуждение к карантину, стресс на работе, невозможность вернуться домой, недоступность алкоголя и других психоактивных веществ. В работе L. Sher [14] предлагается учитывать такие факторы во время пандемии как неопределённость, социальная изоляция и экономические проблемы. Уязвимыми к этим факторам оказываются люди с существующими психиатрическими проблемами, с психологическим неблагополучием,
People with mental disorders may experience worsening of symptoms, while others may develop new mental health issues, such as depression, anxiety and posttraumatic stress (all these conditions are linked with the heightened suicide risk). Suicide risk may also grow because of the stigma towards people with COVID-19 and their families. The loss of job and financial factors of stress are the known factors of suicide risk as well [12].

Apart from the fear of contagion, of own illness and death, and those of close others, the COVID-19 pandemic and methods to counter it create important external conditions, which significantly heighten the suicide risk. There is an increased level of uncertainty in all spheres of life, which is always more badly tolerated, than the certainty in bad things happening in life [13], and it heightens the suicide risk not only in people with psychiatric diagnoses, but also in people with reduced stress tolerance [14]. People with reduced tolerance to uncertainty experience high levels of stress. The decrease in tolerance to uncertainty heightens the effects of other risk factors for suicide [15]. For example, it is shown that the lack of tolerance to uncertainty heightens suicidality in morally traumatic situations in combat veterans [16]. Besides, low tolerance to uncertainty is positively correlated with the feeling of hopelessness [17], which is also one of the important suicide risk factors.

Along with that, the significant suicide risk factor is the heightened sensitivity to existing restrictions. It may be described as the impossibility to accept the existing or emerging restrictions, which do not coincide with the inner view of a person on how it should be [18].

The adverse effects of the pandemic, including suicide risk, may be exacerbated by the influence of selfisolation and physical distancing [14, 19]. E. Durkheim stated that social bonds are the critical factor of emotional health [20]. The research shows that social isolation (for example, living alone) and subjective feeling of loneliness are connected with suicidal 
проживающие в местах с высоким риском заражения, люди, потерявшие близких из-за коронавируса. Воздействие неблагоприятных факторов может привести к появлению или усилению психопатологических проявлений таких как депрессивное расстройство, тревожное расстройство, зависимость от психоактивных веществ. И этих людей следует рассматривать как группу повышенного суицидального риска.

Связь депрессивной симптоматики и суищидального рис$\kappa a$ широко известна, особенно явно она подтверждается в исследованиях на клинических выборках в группах с суицидальными попытками. Реактивные и эндогенные депрессии являются психопатологическими предикторами суицидального (аутоагрессивого) поведения. Например, по мнению А. Берман, некурабельная и недиагностированная депрессия имеется у большинства людей, совершающих суицид [28]. При этом данные о суицидальном риске у людей с эндогенной депрессией разнятся [29], чаще всего исследователи говорят о $70 \%$ и $15 \%$ для суицидальных мыслей и самоубийств соответственно. Ю.Л. Нуллер и И.Н. Михаленко считают, что суицидальные мысли возникают практически у всех больных депрессией, но не всегда они проявляются напрямую [30]. Исследования в США показывают, что более $90 \%$ жертв суицида имеют психические расстройства, а депрессия является основным фактором риска самоубийства, на долю которого приходится до 60\% самоубийств [31].

Пандемия COVID-19 продолжается уже почти 9 месяцев, поиск, по ключевым словам, «депрессия», «суицид», «covid19» по международным базам научных статей за 2020 год даёт уже более 8200 результатов. Распространённый подход при анализе роста депрессивности и суицидальности - рассматривать депрессию во время пандемии как опосредующий фактор, влияющий на суицидальность. На фоне пандемии растёт депрессия, и уже повышение депрессивности рассматривается как фактор роста суицидальных идей. Несмотря на то, что депрессивность и суицидальность тесно связаны, мы в нашем исследовании рассматривали их как две характеристики, на которые во время пандемии могут оказывать влияние разные факторы.

Целью исследования являлся анализ роста депрессивной симптоматики и суицидальных идей во время пандемии COVID-19.

Материалы и методы.

Материалом для исследования стали данные анонимного интернет - опроса, проведённого с 22 марта по 22 июня 2020 года. Опрос включал в себя социодемографические вопросы, вопросы о том, как респондент оценивает своё состояние во время пандемии COVID-19. Среди них был вопрос, беспокоили ли его последнее время мысли о том, чтобы покончить с собой, который позволял выбор по шкале Лайкерта от 0 до 4. Использовались опросники: Симптоматический опросник SCL-90-R (Simptom Check List-90-Revised) [32, 33], содержащий шкалы, отражающие выраженность психопатологической симптоматики, использовалась шкала «депрессии»; Опросник COPE - [34] в адаптации Е.И. Рассказовой с коллегами [35], предназначенный для измерения ситуационных ideation and behavior [14, 21, 22, 23].

The scope of the COVID-19 pandemic is so huge that it is difficult to find an event in the previous years that would match in consequences. The Spanish flu epidemic was associated with an increase in suicide deaths in 1918-1919 [24], which were attributed to the disruption of social bonds during the epidemic and to the fears caused by it. During the 2003 outbreak of severe acute respiratory syndrome in Hong Kong, there was a significant increase in suicide deaths among people aged 65 and older [25]. The research shows that this increase may be associated both with the fears to contract a disease, with the fears to become a burden for a family, and with social isolation.

The increase in suicidal ideation during the COVID-19 pandemic is already found in several studies [26]. The real 68 cases of suicide in India during the pandemic [27] had been analyzed taking into account the fear of contagion, financial losses, loneliness, social isolation, forced quarantine, stress at work, inability to return home, unavailability of alcohol and other psychoactive substances. In the article by L. Sher [14] it was suggested to consider such factors during the pandemic as uncertainty, social isolation and economic problems. Vulnerable to these factors are people with existing psychiatric issues, with psychological ill-being, living in regions with higher risk of contagion, those who lost significant others due to COVID-19. The impact of adverse factors may lead to emergence or worsening of psychopathological manifestations, such as depressive disorder, anxiety disorder, and drug addiction. And these people should be viewed as a group of heightened suicide risk.

The association of depressive symptoms and suicidal risk is widely known, especially clearly it is confirmed in clinical studies on groups with suicide attempts. Reactive and endogenous depressions are the psychopathological predictors of suicidal (autoaggressive) behavior. For example, in the opinion of A. Berman, uncured and undiagnosed depression is present in most people, who try a suicide [28]. But the data on suicide risk 
копинг - стратегий и лежащих в их основе диспозиционных стилей.

Оценивалось изменение депрессивной симптоматики и выраженности суицидальных идей с течением времени. Для этого ответы были разбиты на 3 группы: ответы, полученные 22 марта - 30 марта - до принятия официальных мер борьбы с пандемией COVID-19 в России; 31 марта - 12 мая - введение режима самоизоляции и других мер противодействия пандемии; 12 мая - 22 июня - ослабление и постепенная отмена ограничений.

Для статистического анализа использовались методы корреляционного анализа (Spearman). Тренд роста депрессивной симптоматики оценивался с помощью критерия Джонкхиера-Терпстра (Jonckheere-Terpstra test). Сравнение частоты суицидальных ответов в разные периоды времени проводилось с помощью точного критерия Фишера (Fisher's Exact Test). Для сравнения групп по параметрам, выраженным в дихотомической шкале, использовался критерий $\chi^{2}$. Для графика использовалась стандартизованная (нормированная) оценка (z-score), показывающая отклонения наблюдения от среднего значения в группе, что дало возможность привести распределения параметров к одному масштабу и объединить в одном графике. Для анализа использовалась программа SPSS.

Результаты исследования.

В исследовании представлен анализ ответов на опрос, полученных с 22.03.20 г. по 22.06.20 г., всего ответило 908 человек. Приведены только статистически значимые результаты.

Анализ показал статистически значимую положительную корреляцию между выраженностью суицидальных мыслей и психопатологической симптоматикой в SCL-90. Самый высокий коэффициент корреляции с депрессивной симптоматикой (коэффициент Спирмена 0,450; $<00,001)$.

Изменения во времени. Для оценки изменений депрессивной симптоматики и суицидальных идей во время пандемии COVID-19 в России были выделены 3 периода времени, связанные с изменением мер противодействия пандемии.

I. 22 марта - 30 марта (220 человек) - до принятия официальных мер борьбы с пандемией.

II. 31 марта - 12 мая (495 человек) - введение «выходных дней», что в реальности означает карантин и ограничения передвижения, режим самоизоляции.

III. 12 мая - 22 июня (193 человека) - окончание выходных дней, ослабление и постепенная отмена ограничений

Группы респондентов, ответивших на опрос в эти периоды времени, не отличались по таким социодемографическимим показателям как пол и возраст. В группе респондентов, ответивших 12 мая - 22 июня был выше процент людей со средним образованием, чем в группе ответивших в марте. Однако во всех группах большинство ответивших имели высшее образование, и по этому показателю группы статистически не различались (табл. 1). in people with endogenous depression vary [29], more often the researchers speak of the $70 \%$ and $15 \%$ of suicidal thoughts and suicides, correspondingly. Yu.L. Nuller and I.N. Mikhalenko state that suicidal thoughts appear almost in all depressive patients, but not always they act on them [30]. The research in the USA shows that more that $90 \%$ of those who died by suicide had had mental disorders, and depression is the main risk factor for suicide, which accounts for $60 \%$ of suicides [31].

The COVID-19 pandemic has been going on for almost 9 months, and the search by the keywords «depression», «suicide», «covid-19» in the international databases with academic articles for the year 2020 returns more than 8200 results. The most widespread approach for the analysis of increase in depression and suicidality is to view depression during the pandemic as a mediating factor, which impacts the suicidality. During the pandemic, depression increases, and this increase per se is viewed as a factor of increased suicidal ideation. Though depression and suicidality are closely connected, in our study we viewed them as two separate characteristics, which may be influenced by different factors during the pandemic.

The study objective was to analyze the increase in depressive symptoms and suicidal ideation during the COVID-19 pandemic.

Materials and methods.

In the study, the data from the anonymous internet survey was analyzed, conducted from March, 22, 2020 to June, 22, 2020. The survey included sociodemographic questions and questions on how the respondent assesses their conditions during the COVID-19 pandemic. Among those there was a question, whether they were recently bothered by the thoughts of killing themselves, with the estimation on the Likert scale from 0 to 4 . The questionnaires used were the Symptom Check List 90-Revised [32, 33], which included the scales that reflect the severity of the psychopathological symptoms, including the 'depression' scale; and the COPE Inventory [34], adapted by E.I. Rasskazova et al. [35], designed to measure situational coping strategies and underlying dispositional styles. 
Социодемографические характеристики групп

Sociodemographic characteristics of the groups

\begin{tabular}{|c|c|c|c|c|c|c|c|c|c|}
\hline \multirow{3}{*}{$\begin{array}{l}\text { Показатель } \\
\text { Indicator }\end{array}$} & \multirow{2}{*}{\multicolumn{2}{|c|}{$\begin{array}{c}\text { Bсего / Total } \\
n=908\end{array}$}} & \multirow{2}{*}{\multicolumn{2}{|c|}{$\frac{22-30.03 .2020}{n=220}$}} & \multirow{2}{*}{\multicolumn{2}{|c|}{$\frac{31.03-12.05 .2020}{\mathrm{n}=495}$}} & \multirow{2}{*}{\multicolumn{2}{|c|}{$\frac{12.05-22.06 .2020}{\mathrm{n}=193}$}} & \multirow{3}{*}{$\mathrm{p}$} \\
\hline & & & & & & & & & \\
\hline & $\mathrm{n}$ & $\%$ & $\mathrm{n}$ & $\%$ & $\mathrm{n}$ & $\%$ & $\mathrm{n}$ & $\%$ & \\
\hline $\begin{array}{l}\text { Пол / Gender: } \\
\text { мужчины / males }\end{array}$ & 138 & 15,2 & 27 & 12,3 & 85 & 17,2 & 26 & 13,5 & 0,182 \\
\hline Женщины / females & 770 & 84,8 & 193 & 87,7 & 410 & 82,8 & 167 & 86,5 & \\
\hline Возраст, лет / Age & \multicolumn{2}{|c|}{$40,848 \pm 11,8$} & \multicolumn{2}{|c|}{$40,4 \pm 11,3$} & \multicolumn{2}{|c|}{$41,3 \pm 12,2$} & \multicolumn{2}{|c|}{$40,8 \pm 11,6$} & 0,393 \\
\hline \multirow{4}{*}{$\begin{array}{c}\text { Образование / Education: } \\
\text { среднее } \\
\text { Secondary } \\
\text { высшее } \\
\text { Higher } \\
\text { уч. степень } \\
\text { PhD }\end{array}$} & & & & & & & & & 0,022 \\
\hline & 85 & 9,4 & 13 & 5,9 & 45 & 9,1 & 27 & 14,0 & \\
\hline & 707 & 77,9 & 177 & 80,5 & 380 & 76,8 & 150 & 77,7 & \\
\hline & 116 & 12,8 & 30 & 13,6 & 70 & 14,1 & 16 & 8,3 & \\
\hline
\end{tabular}

Анализ показал статистически значимый тренд роста депрессивной симптоматики по мере развития пандемии COVID-19 в России - чем больше времени прошло от начала пандемии в России, тем выше выраженность симптоматики (критерий Джонкхиера-Tерпстра, Std. J-Tstat $=2,51 ; \mathrm{p}=0,012$ ), средние значения депрессивной симптоматики по SCL-90R $(0,75 \pm 0,70$ в начале опроса; $0,81 \pm 0,66$ в середине; $0,93 \pm 0,81$ в конце опроса). На рис. 1 показаны средние значения депрессивной симптоматики и выраженности мыслей о суициде в заданные периоды времени. Для наглядности использована стандартизованная (нормированная) оценка (z-score) для обоих параметров.

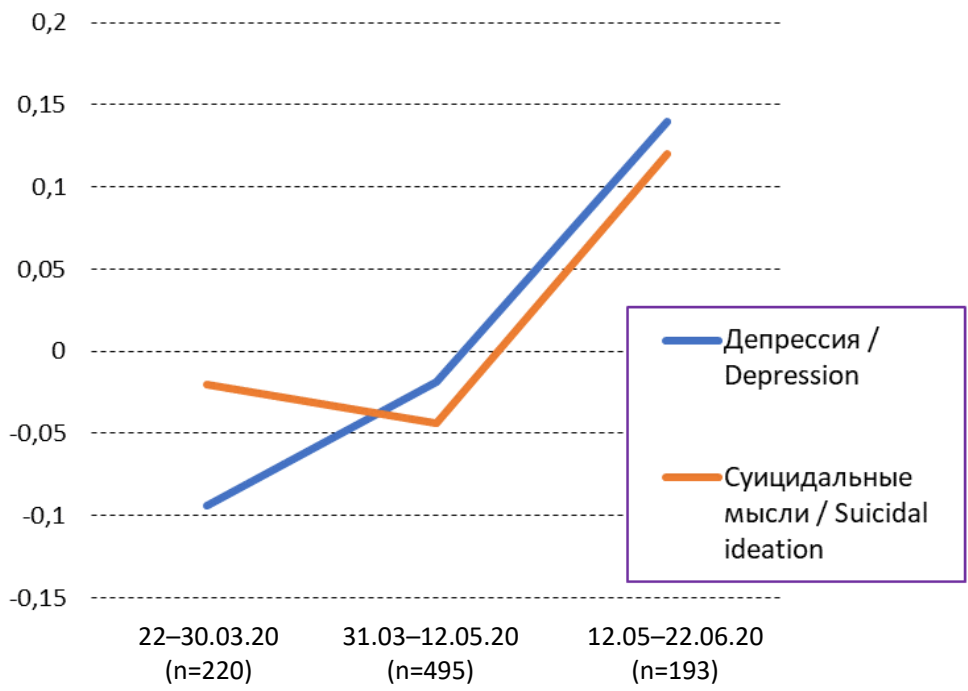

Puc. 1. / Fig. 1. Динамика показателей «Депрессии» (по SCL-90R) и выраженности мыслей о суициде: средние стандартизированные значения (z-score) / Dynamics of the indicators 'Depression' (according to the SCL-90-R) and 'Intensity of Suicidal Thoughts': mean standardized scores (z-scores).

Рост суицидальных мыслей наблюдается в конце опроса.
The change in depressive symptoms and intensity of suicidal ideation with time also was assessed. For that reason, answers were split in 3 groups: those received from March, 22 to March, 30 - before the official measures to counter the COVID-19 pandemic were undertaken; from March, 31 to May, 12 - during the selfisolation regime and other measures to counter the pandemic; May, 12 to June, 22 - during the weakening and gradual abolition of the restrictions.

The statistical methods used were following: correlation analysis (Spearman's coefficient); the growth trend in depressive symptoms was assessed with the Jonckheere-Terpstra test; the comparison of frequencies in answers about suicidal thoughts in different periods of the pandemic was performed with the Fisher's Exact Test; to compare the groups in parameters, expressed in dichotomous scale, $\chi^{2}$ criterion was used; a standardized (normalized) score (z-score) was used for the graph, which showed the deviations in observation from the mean in different groups, and allowed to bring the parameter distributions to one scale and combine them in one graph. The analysis was performed in SPSS program.

Study results.

The study presents the analysis of responses to the survey, performed from March, 22, to June, 22, 2020, in which 908 people took part. Only statistically significant results are presented. 
При этом статистически значимо не растёт частота положительных ответов о суицидальных мыслях (любой выбор в вопросе о суицидальных идеях кроме «совсем нет») - в начале опроса $13 \%$; в середине $11,7 \%$; в конце $16,5 \%\left(\chi^{2}=2,895\right.$; $\mathrm{p}=0,235)$, но к концу опроса растет их интенсивность. Вопрос про наличие суицидальных идей позволял выбор из 5 вариантов («совсем нет», «немного», «умеренно», «сильно», «очень сильно»). Рассмотрение частоты ответов, в которых выраженность суицидальных мыслей «сильно» и «очень сильно», показывает статистически значимый рост в последний период времени (рис. 1 и 2) (Fisher's Exact Test 5,92; p=0,046).

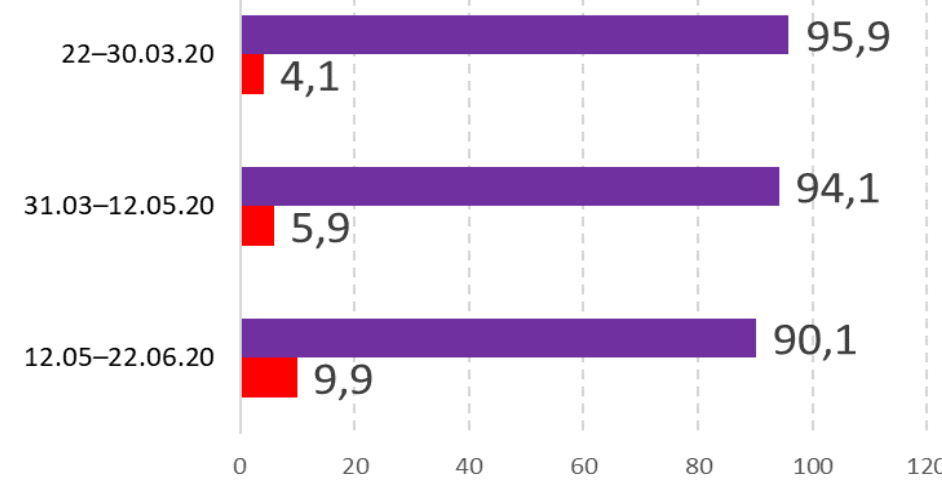

нет суицидальных мыслей или низкий уровень выраженности мыслей о суициде / No suicidal thoughts or suicidal thoughts of low level of intensity мысли о суициде выражены «сильно» и «очень сильно»

Suicidal thoughts, reported as "strong" and "very strong"

Puc. 2. / Fig. 2. Частота выраженности мыслей о суициде «сильно» и «очень сильно» в разные периоды времени / The frequency of intensity in suicidal thoughts: 'strong' and 'very strong' in different time periods, $\%$.

Социодемографические показатели. Корреляционный анализ показал статистически значимую отрицательную связь выраженности депрессивной симптоматики с возрастом, наличием семьи и детей. Эти же связи справедливы и для выраженности суицидальных идей (табл. 2). Выраженность депрессивной симптоматики во время пандемии зависит от пола и выше у женщин, в то время как выраженность суицидальных мыслей выше у мужчин.

Оиенка опасности пандемии, страхи за себя и близких. Выраженность депрессии статистически значимо связана с текущей ситуацией пандемии. Она растёт с появлением вируса в городе, с появлением заболевших среди знакомых, с увеличением страхов заболеть и умереть, страхов смерти других. Чем выше показатель депрессии, тем больше используется способов защиты от заражения. При более высоких показателях депрессивной симптоматики своё материальное положение респонденты оценивают, как менее благополучное, и считают, что оно ухудшается (разделы «Оценка опасности пандемии, страхи за себя и близких» и «Способы защиты» в табл. 2). Суицидальные мысли не связаны с появлением больных в городе и среди знакомых, со страхами заражения себя и близких.
The analysis showed a statistically significant positive correlation between the intensity of suicidal thoughts and psychopathological symptoms according to SCL-90-R. The highest correlation coefficient was with the depressive symptoms (Spearman's coefficient, .45, $\mathrm{p}<.001)$.

Changes in time. To assess the changes of depressive symptoms and suicidal ideation during the COVID-19 pandemic in Russia, 3 time periods were identified, which corresponded to the changes in the response to the pandemic.

1. March, 22 - March, 30 (220 people) - before the official measures to counter the pandemic were undertaken.

2. March, 31 - May, 12 (495 people) - introduction of 'days off,' which in reality meant quarantine and restrictions on travels and transportation, self-isolation regime.

3. May, 12 - June, 22 (193 people) - the end of 'days off,' weakening and gradual abolition of restrictions.

The groups of respondents, who took part in the survey during these periods of time, did not differ in sociodemographic characteristics of gender and age. In the $3^{\text {rd }}$ group there was a higher percentage of people with secondary education, in comparison to the $1^{\text {st }}$ and $2^{\text {nd }}$ group. But in all groups the majority had higher education, and on this indicator the groups did not differ statistically (Table 1 ).

The analysis showed a statistically significant growth trend in depressive symptoms during the course of the COVID-19 pandemic in Russia: the more time has passed from the start of the pandemic in Russia, the higher was the severity of symptoms (JonckheereTerpstra test, Std. J-T stat. $=2.51, \mathrm{p}=$ .012 ), the mean indices of depressive symptoms according to SCL-90-R are $.75 \pm .7$ at the start of the survey; $.81 \pm$ .66 in the middle, $.93 \pm .81$ in the end. The Graph 1 shows the mean values of depressive symptoms and the intensity of suicidal thoughts in these periods of time. For clarity, we used a standardized (normalized) score (z-score) for both parameters.

The increase in suicidal thoughts is seen in the last period of the study ( $3^{\text {rd }}$ group). Though there is no statisti- 
Таблийа 2 / Table 2

Связь депрессивной симптоматики и мыслей о суициде с социодемографическими показателями и оценкой своего состояния (корреляции по Спирмену)

The correspondence of depressive symptoms and suicidal thoughts with sociodemographic indicators and assessment of personal conditions (Spearman's correlations)

\begin{tabular}{l|c|c}
\hline \multicolumn{1}{c|}{$\begin{array}{c}\text { Показатель } \\
\text { Indicator }\end{array}$} & $\begin{array}{c}\text { Депрессия } \\
\text { Depression }\end{array}$ & $\begin{array}{c}\text { Мысли о суициде } \\
\text { Suicidal thoughts }\end{array}$ \\
\hline \multicolumn{2}{c}{$\begin{array}{c}\text { Социодемографические показатели } \\
\text { Sociodemographic indicators }\end{array}$} \\
\hline $\begin{array}{l}\text { Boзраст } \\
\text { Age }\end{array}$ & $-0,220 * *$ & $-0,170^{* *}$ \\
\hline $\begin{array}{l}\text { Пол } \\
\text { Gender }\end{array}$ & $0,138^{* *}$ & $-0,092^{*}$ \\
$\begin{array}{l}\text { Семейное положение } \\
\text { Family status }\end{array}$ & $-0,106^{*}$ & $-0,107^{*}$ \\
\hline $\begin{array}{l}\text { Наличие детей } \\
\text { Сhildren }\end{array}$ & $-0,212 * *$ & $-0,210^{* *}$ \\
\hline
\end{tabular}

Оценка опасности пандемии, страхи за себя и близких Assessing the risks of the pandemics, fears for the self and close others

\begin{tabular}{l|c|c}
\hline $\begin{array}{l}\text { Вирус в городе } \\
\text { Virus in the city }\end{array}$ & $0,121^{*}$ & \\
\hline $\begin{array}{l}\text { Вирус у знакомых } \\
\text { Virus in friends }\end{array}$ & $0,165^{* *}$ & \\
\hline $\begin{array}{l}\text { Боюсь тяжело заболеть } \\
\text { Fear of severe illness }\end{array}$ & $0,132^{*}$ & \\
\hline $\begin{array}{l}\text { Боюсь умереть } \\
\text { Fear of dуing }\end{array}$ & $0,188^{* *}$ & \\
\hline $\begin{array}{l}\text { Боюсь тяжелого состояния } \\
\text { или смерти других }\end{array}$ & $0,112^{*}$ & \\
$\begin{array}{l}\text { Fear of severe illness or death } \\
\text { of others }\end{array}$ & $-0,107 *$ & \\
\hline $\begin{array}{l}\text { Изменение материального } \\
\text { положения } \\
\text { Сhange in financial status }\end{array}$ & $-0,114 *$ & \\
$\begin{array}{l}\text { Материальное благополучие } \\
\text { Financial prosperity }\end{array}$ &
\end{tabular}

Способы защиты

Methods of protection

\begin{tabular}{l|c|c}
\hline $\begin{array}{l}\text { Не покидаю дом } \\
\text { I don't leave my home }\end{array}$ & $0,100^{*}$ & \\
\hline $\begin{array}{l}\text { Ношу маску } \\
\text { I wear a mask }\end{array}$ & $0,099^{*}$ & \\
\hline $\begin{array}{l}\text { Ношу перчатки } \\
\text { I wear gloves }\end{array}$ & & $-0,079 *$ \\
\hline $\begin{array}{l}\text { Сумма способов } \\
\text { Sum of methods }\end{array}$ & $0,116^{*}$ & \\
\hline $\begin{array}{l}\text { Делали запасы } \\
\text { I stocked up }\end{array}$ & $0,143^{* *}$ & \\
\hline
\end{tabular}

Оценка своего физического состояния Assessment of physical state

\begin{tabular}{l|c|c}
\hline $\begin{array}{l}\text { Заболевания обмена веществ } \\
\text { Metabolic conditions }\end{array}$ & $0,102 *$ & \\
\hline $\begin{array}{l}\text { Иммунодефицит } \\
\text { Immunodeficiency }\end{array}$ & $0,119^{*}$ & \\
\hline
\end{tabular}

cally significant increase in positive answers about suicidal thoughts (any answer except 'not at all'): in the beginning of the study there were $13 \%$ of such answers, $11.7 \%$ in the middle and $16.5 \%$ in the end $\left(\chi^{2}=2.895 ; \mathrm{p}=.235\right)$; but it is the intensity that increases towards the end. The question about the presence of suicidal ideation allowed for the choice of 5 options ('not at all,' 'a little,' 'moderate,' 'strong,' 'very strong'). The analysis of frequencies of answers with the intensity of suicidal thoughts as 'strong' and 'very strong,' shows the statistically significant increase in the last period of time (Fig. 1 and 2, Fisher's Exact Test, 5.92; $\mathrm{p}=.046)$.

Sociodemographic parameters. Correlation analysis showed statistically significant negative association of the severity of depressive symptoms with age, family status and presence of children. The same correlations are valid for the intensity of suicidal ideation (Table 2). The severity of depressive symptoms during the pandemic depends on gender and is higher in women, while the intensity of suicidal thoughts is higher in men.

Assessing the risk of the pandem$i c$, fears for the self and close others. The severity of depression was statistically significantly correlated with the current situation of the pandemic. It grows with the emergence of the virus in the city, with the friend falling ill, with the increase in fears of getting sick and die, fears of death of others. The higher is the index of depression, the more methods of protection from the infection are used. With the higher index of depressive symptoms, respondents assessed their financial status as less prosperous, and stated that it deteriorates (see parts Assessing the risk of the pandemic, fears for the self and close others and methods of protection in Table 2). Suicidal thoughts had no connection with the emergence of sick people in the city and among friends, with the fears of contracting the disease and infecting close others.

Assessing own physical and mental state. The severity of depression statistically significantly correlates with the presence of various somatic conditions (or suspicions of their presence) and with identifying the self with 


\begin{tabular}{l|c|c}
\hline $\begin{array}{l}\text { Не указанные заболевания } \\
\text { Other conditions }\end{array}$ & $0,129 * *$ & \\
\hline $\begin{array}{l}\text { Отношусь к группе риска } \\
\text { I am in the risk group }\end{array}$ & $0,099 *$ & \\
\hline
\end{tabular}

Оценка своего психологического состояния Assessment of psychological state

\begin{tabular}{l|c|c}
\hline $\begin{array}{l}\text { Готов рисковать } \\
\text { Proneness to risk }\end{array}$ & $0,109 * *$ \\
\hline $\begin{array}{l}\text { Тревога } \\
\text { Anxiety }\end{array}$ & $0,494^{* *}$ & $0,233^{* *}$ \\
\hline $\begin{array}{l}\text { Хороший сон } \\
\text { Sleep well }\end{array}$ & $-0,352^{* *}$ & $-0,140^{* *}$ \\
\hline $\begin{array}{l}\text { Подавленность } \\
\text { Distress }\end{array}$ & $0,682 * *$ & $0,322^{* *}$ \\
\hline $\begin{array}{l}\text { Aктивность } \\
\text { Activity }\end{array}$ & $-0,120^{*}$ & \\
\hline $\begin{array}{l}\text { Нужна помощь психолога } \\
\text { Need a psусhologist }\end{array}$ & $0,465^{* *}$ & $0,231^{* *}$ \\
\hline
\end{tabular}

Примечания / Notes: * $\mathrm{p}<0,05 ; * * \mathrm{p}<0,01$

Оиенка своего состояния. Выраженность депрессии статистически значимо коррелирует с наличием различных соматических заболеваний (или подозрений в их наличии) и с отнесением себя к группе риска по заражению коронавирусом (раздел «Оценка своего физического состояния» в табл. 2).

Не выявлено связи суицидальных мыслей с наличием соматических заболеваний. При этом и при депрессивной симптоматике, и при суицидальных идеях выявлена связь с оценкой своего психологического состояния как менее благополучного (тревогой, подавленностью, нарушениями сна). Однако в отличие от депрессивной симптоматики, которая связана со снижением активности, выраженность суицидальных идей со снижением активности не связана (раздел «Оценка своего психологического состояния» в табл. 2). Кроме того, при повышении выраженности суицидальных идей растёт готовность к риску.

Опросник СОРЕ. Анализ связи способов совладания со стрессовой ситуацией во время пандемии COVID-19 с выраженностью депрессивной симптоматики и выраженностью суицидальных идей показал значимые положительные корреляции и депрессии, и выраженности суицидальных мыслей с показателями мысленного ухода, концентрации на эмоциях, отрицания, поведенческого ухода от проблемы, использованием успокоительных или алкоголя, и отрицательные корреляции с положительным переформулированием, активным совладанием, использованием юмора (табл. 3). При этом выраженность депрессивной симптоматики связана с более высоким уровнем использования инструментальной поддержки, эмоциональной социальной поддержки. Связи выраженности суицидальных мыслей с использованием поддержки не выявлено. При росте мыслей о суициде снижается принятие и планирование, для депрессии такой зависимости не выявлено. the risk group for coronavirus (part Assessment of physical state, Table 2).

There was no correlation between suicidal thoughts and the presence of somatic conditions. Along with that, both depressive symptoms and suicidal ideation were associated with the assessment of own psychological state as less satisfactory (with anxiety, distress, sleep disturbance). But, as opposed to depressive symptoms, which were associated with lack of activity, the intensity of suicidal ideation had no such link (part Assessment of psychological state, Table 2). Besides, the increase in suicidal ideation corresponds to proneness to risky behavior.

COPE Inventory. The analysis of associations between the coping strategies with the stressful situation during the COVID-19 pandemic, severity of depressive symptoms and intensity of suicidal ideation showed significant positive correlations between both depression and suicidal ideation and indicators of mental disengagement, focus on emotions, denial, behavioral disengagement, substance use, and negative correlations with positive reinterpretation, active coping, humor (Table 3). At the same time, the severity of depressive symptoms was more strongly connected with the high level of instrumental and emotional social support. There was no association between the intensity of suicidal thoughts and use of social support. With the increase in suicidal thoughts the acceptance and planning deteriorated, while no such link was found for depression.

Discussion.

The analysis of the survey results showed a significant increase in depressive symptoms over the whole period of the study, as well as the increase in intensity of suicidal ideation in the end of the study. Interestingly, the US research in June, which studied the influence of the COVID-19 pandemic on suicidal ideation, yielded very similar results, and the authors note that approximately twice as much respondents reported serious suicidal intents, as compared to 2018 (10.7\% vs. $4.3 \%$ ) [26]. At the start of our study, the frequency of serious intents was $4.5 \%$, as compared to $9.9 \%$ in the end. 
Таблица 3 / Table 3

Связь депрессивной симптоматики и мыслей о суициде с копинг стратегиями (корреляции по Спирмену)

The correspondence of depressive symptoms and suicidal thoughts with coping strategies (Spearman's correlations)

\begin{tabular}{|c|c|c|}
\hline $\begin{array}{l}\text { Опросник COPE } \\
\text { COPE Inventory }\end{array}$ & $\begin{array}{l}\text { Депрессия } \\
\text { Depression } \\
\end{array}$ & $\begin{array}{l}\text { Мысли о суициде } \\
\text { Suicidal thoughts }\end{array}$ \\
\hline $\begin{array}{l}\text { Положительное } \\
\text { переформулирование } \\
\text { Positive reinterpretation }\end{array}$ & $-0,211 * *$ & $-0,186^{* *}$ \\
\hline $\begin{array}{l}\text { Мысленный уход } \\
\text { Mental disengagement }\end{array}$ & $0,384 * *$ & $0,122 *$ \\
\hline $\begin{array}{l}\text { Концентрация на эмоциях } \\
\text { Focus on emotions }\end{array}$ & $0,442 * *$ & $0,167 * *$ \\
\hline $\begin{array}{l}\text { Использование } \\
\text { инструментальной поддержки } \\
\text { Instrumental social support }\end{array}$ & $0,174 * *$ & \\
\hline $\begin{array}{l}\text { Активное совладание } \\
\text { Active coping }\end{array}$ & $-0,184 * *$ & $-0,176^{* *}$ \\
\hline $\begin{array}{l}\text { Отрицание } \\
\text { Denial }\end{array}$ & $0,253 * *$ & $0,159 * *$ \\
\hline $\begin{array}{l}\text { Юмор } \\
\text { Humor }\end{array}$ & $-0,167 * *$ & $-0,109^{*}$ \\
\hline $\begin{array}{l}\text { Поведенческий уход } \\
\text { от проблемы } \\
\text { Behavioral disengagement }\end{array}$ & $0,282 * *$ & $0,170 * *$ \\
\hline $\begin{array}{l}\text { Эмоциональная социальная } \\
\text { поддержка } \\
\text { Emotional social support } \\
\end{array}$ & $0,151 * *$ & \\
\hline $\begin{array}{l}\text { Использование успокоительных } \\
\text { Substance use }\end{array}$ & $0,385 * *$ & $0,304 * *$ \\
\hline $\begin{array}{l}\text { Принятие } \\
\text { Acceptance }\end{array}$ & & $-0,116^{*}$ \\
\hline $\begin{array}{l}\text { Планирование } \\
\text { Planning }\end{array}$ & & $-0,202 * *$ \\
\hline
\end{tabular}

Примечания / Notes: *p<0,05; **p<0,01

Обсуждение результатов .

Анализ результатов опроса показал значимый рост депрессивной симптоматики на протяжении всего опроса и рост выраженности суицидальных идей в конце опроса. Интересно, что исследование, проведённое в США в июне, в котором изучается влияние пандемии COVID-19 на суицидальные идеи, даёт очень близкие показатели, авторы отмечают, что примерно вдвое больше респондентов сообщили о серьёзных суицидальных намерениях, чем это было в 2018 году $(10,7 \%$ против $4,3 \%)$ [26]. В нашем исследовании в начале опроса частота серьёзных намерений была $4,5 \%$ и 9,9\% в конце опроса.

Рост выраженности суицидальных мыслей отстает по времени от роста депрессивной симптоматики. Вероятно, суицидальные идеи появляются или усиливаются не сразу, а как отложенный эффект стресса. Возможный отложенный эффект COVID-19 для психического здоровья, включая суицидальное поведение, отмечается и в других исследованиях, подчёркивается, что последствия могут сохраняться в течение длительного времени и достигать пика позже, чем сама пандемия [14].
The increase in intensity of suicidal thoughts lags behind in time from the increase in depressive symptoms. It is likely that suicidal ideation appears or strengthens not at once, but as a delayed effect of stress. The possible delayed effect of the COVID-19 on mental health, including suicidal behavior, is noted in other studies, and it is emphasized that the implications may linger for a long time and reach a peak after the pandemic itself [14].

Depressive symptoms grow throughout the study and are associated with an increase in the immediate threat of the pandemic - the contraction of the coronavirus disease by close others, with fears of getting sick and dying, with the fear for close others, with the presence (or suspicion of presence) of somatic conditions. The increase in suicidal thoughts is manifested not only in the fact that the number of people with such thoughts increases, but also in intensity of such thoughts. It is likely that suicidal thoughts strengthen during the pandemic in those people, who were in the risk group even before the COVID-19, and during the pandemic the intensity of their thoughts increased.

The increase in suicidal thoughts, as well as in depressive symptoms, is associated with non-constructive coping strategies (mental disengagement, focus on emotions, denial, etc.), and, in contrast to depressive symptoms, with lower acceptance and planning.

The association of depressive symptoms with the appearance of the disease in the close circle, with fears for one's own life and lives of significant others, with worries about finances and somatic health, with the amount of protection methods implemented, shows that depressive symptoms are linked with concrete, 'objectified' threats and fears, and respondents with depressive symptoms understand, what it is exactly that they fear, the source of their anxiety, and try undertake measures for their safety, seek for support.

The intensity of suicidal thoughts does not depend on fears and attempts of protection, but is linked with the higher level of anxiety. It is likely that suicidal thoughts intensify with the absence of a concrete threat, with the 
Депрессивная симптоматика растёт на протяжении всего исследования и связана с ростом непосредственной угрозы пандемии - появлением больных коронавирусом в ближнем окружении, со страхами заболеть и умереть, со страхом за близких, с наличием (или подозрением в наличии) соматических заболеваний. Рост мыслей о суициде проявляется в том, что увеличивается не столько количество людей, у которых бывают такие мысли, а степень выраженности этих мыслей. Вероятно, суицидальные мысли усиливаются на фоне пандемии у людей, которые и до появления COVID-19 были в группе риска, и во время пандемии выраженность этих мыслей возросла.

Повышение суицидальных мыслей, как и увеличение депрессивной симптоматики, связано с неконструктивными копингами (мысленным уходом, концентрацией на эмоциях, отрицанием и др.), и в отличие от депрессивной симптоматики, со сниженной способностью к принятию и планированию.

Связь депрессивной симптоматики с появлением заболевших знакомых, со страхами за свою жизнь и жизнь близких, с обеспокоенностью своим материальным положением и своим соматическим здоровьем, с количеством способов защиты показывает, что депрессивная симптоматика связана с тем, что угрозы и страхи конкретны, «объективированы», респонденты с депрессивной симптоматикой понимают, чего именно они боятся, с чем связана их тревога, стараются чтото делать для своей безопасности, ищут поддержку.

Выраженность суицидальных мыслей не зависит от страхов и попыток что-то делать для своей безопасности, при этом связана с более высоким уровнем тревоги. Возможно, суицидальные мысли усиливаются при отсутствии конкретной угрозы, при невозможности «объективировать» свои страхи, найти объяснение своей тревоге в текущей ситуации, «неопределённости» угрозы. Влияние неопределённости на риск суицидального поведения отмечают и другие исследователи, так в исследовании экономической неопределённости [36] показано, что резкий скачок ежедневной экономической неопределенности приводит к немедленному росту самоубийств. Неопределённость может повышать суицидогенное действие других факторов [15]. Непонимание причины своих страхов и тревоги может усиливаться неконструктивным копингом - снижением способности к планированию, так как планирование способно снизить субъективное ощущение неопределённости.

Если при росте депрессивной симптоматики наблюдается рост копинг стратегий, связанных с поиском социальной поддержки, при суицидальных мыслях не выявлено такой связи. Это может быть связано с трудностями поддерживать социальные контакты и усиливать ощущение одиночества, ряд исследований показывает, что социальная изоляция и ощущение одиночества связаны с суицидальными идеями и поведением [21, 22].

Так как неопределённость угрозы не дает возможность дать ей рациональное объяснение, найти материальное воплощение, могут быть трудности принятия ситуации, и суицид может рассматриваться как один из способов выхода из сложной ситуации, когда «смерть» воспринимается как освобождение от страданий и мучений, переносимых в жизни inability to 'objectify' fears, to find an explanation for own anxiety in a current situation, with the 'uncertainty' of a threat. The influence of uncertainty on the risk for suicidal behavior is noted by other researchers, for example, the study of economic uncertainty [36] showed that the sudden jump in daily economic uncertainty leads to immediate increase in suicides. Uncertainty can also increase other risk factors for suicide [15]. Failure to understand the causes of own fears and anxieties can be amplified by a non-constructive coping strategy - the reduced planning ability, as planning can lower the subjective sense of uncertainty.

While the increase in depressive symptoms is seen to be accompanied by the increase in coping strategies associated with search for social support, there is no such link with suicidal thoughts. It may be due to the difficulties in maintaining social contacts and the strengthening of feeling of loneliness, as a number of studies show that social isolation and feeling of loneliness are linked with suicidal ideation and behavior [21, 22].

As far as uncertainty of a threat does not allow to ascribe it a rational explanation, to find a material realization, it may be difficult to accept the situation, and suicide may be viewed as one of the ways to escape the difficult situation, when 'death' is perceived as a liberation from life sufferings and turmoil [37]. Along with that, the link between the intensity of suicidal ideation and the increased willingness to take risks, as well as the absence of reduced activity, strengthen the risk of suicidal behavior. And the reduced planning leads to impulsive, reckless decisions.

Another 'invisible' risk factor of suicidal ideation may be the increased sensitivity to constraints. This factor is extensively described by various researchers and clinicians. Thus, E. Shneidman describes it through the desire to control everything and intolerance of the situation, when one is left at the mercy of other people or circumstances and feels powerless in front of them [38]. Such personal traits may be attributed to narcissistic personality disorder, which is known to have a marked suicidal risk [39]. The frame- 
[37]. При этом связь выраженности суицидальных идей с ростом готовности к риску и одновременное отсутствие снижения активности повышают риск суицидального поведения. А снижение «планирования» приводит к импульсивным необдуманным решениям.

Ещё одним «невидимым» фактором риска роста суицидальных идей может быть повышенная чувствительность к имеющимся ограничениям. Этот фактор с разных сторон описывается многими исследователями и клиницистами. Так, Э. Шнейдман описывает его через стремление всё контролировать и непереносимость для человека ситуации, когда он находится во власти других людей или обстоятельств и ощущает бессилие перед ними [38]. Такие личностные особенности можно отнести к нарциссическому расстройству, для которого отмечается повышенный суицидальный риск [39]. Но в рамках нашего исследования гипотеза о личностных особенностях не рассматривалась и может быть направлением дальнейших исследований.

При анализе роста депрессивной симптоматики явно видна значимость других людей как в ощущении опасности ситуации пандемии, так и в способах совладания с тревогой. Рост депрессивной симптоматики связан с переживанием о других людях, с появлением заболевших людей рядом, приводит к увеличению используемых способов защиты, которые как известно защищают в первую очередь других людей. Способы справиться со стрессом также ориентированы на других людей - при высоком уровне депрессивной симптоматики растёт потребность в социальной поддержке. При росте суицидальных идей «другие» люди не влияют на ощущение опасности, отсутствуют переживания за них, а способы совладания с ситуацией также не связаны с другими.

Выводы.

Несмотря на то, что депрессивная симптоматика является важным фактором суицидального риска, наше исследование показало, что во время пандемии COVID-19 рост депрессивной симптоматики и суицидальных мыслей обусловлены разными факторами.

Рост депрессивной симптоматики связан с различными страхами и опосредован неконструктивными способами совладания со стрессом. Однако присутствуют и конструктивные копинг стратегии - поиск поддержки.

Выраженность мыслей о суициде растёт на фоне пандемии COVID-19 и связана с высоким уровнем стресса, который не объясняется «объективной» угрозой заражения и страхами за свою жизнь и жизнь близких, а переживается ими как «неопределённая» тревога, вероятно связанная с мерами противодействия пандемии - ограничениями социального взаимодействия, одиночеством, неопределённостью.

Увеличение показателей депрессивной симптоматики связано с ориентацией на «другого» человека, а выраженность суицидальных идей никак с этим не связана. Дальнейшим направлением исследования может быть изучение связи выраженности суицидальных идей во время пандемии с личностными особенностями и социальной перцепцией.

Ограничения исследования: несбалансированность выборки по полу; ограничения, касающиеся методов самоотчёта; относительно небольшой процент людей с суицидальными идеями в общей выборке. work of our study did not allow posing a hypothesis about personal traits, so it may become a question for further study.

The analysis of increase in depressive symptoms clearly shows the importance of other people, both in the feeling of danger in the situation of pandemic, and in the ways to cope with anxiety. The increase in depressive symptoms is linked with worries for other people, with contraction of the disease in the close circle, and leads to an increase in implemented protection methods, which, as is known, protect other people, in the first place. The ways to cope with stress are also oriented to others, as with an increase in depressive symptoms the need for social support grows. With an increase in suicidal ideation, 'others' have no impact on the feeling of danger, there is no worry for them, and the ways of coping with the situation also have no link with other people.

Conclusion.

Though the depressive symptoms are an important suicide risk factor, our study showed that during the COVID19 pandemic the increase in depressive symptoms and suicidal ideation is determined by different factors.

The intensity of suicidal thoughts grows during the COVID-19 pandemic and is associated with the high level of stress, which is not explained by an 'objective' threat of contagion and fears for own life and lives of others, but is felt as an 'uncertain' anxiety, probably associated with the measures to counter the pandemic - with restrictions on social interactions, loneliness, uncertainty.

The increase in depressive symptoms is associated with orientation to 'another' person, while the intensity of suicidal thoughts has no link with it.

The further direction of the research may be a study of the link between the intensity of suicidal ideation during the pandemic, personality traits and social perception.

Limitations of the study: unbalanced sample by gender; limitations of self-report methods; relatively low percentage of people with suicidal ideation in general sample. 


\section{Литература / References:}

1. Holmes E.A., O'Connor R.C., Perry V.H. et al. Multidisciplinary research priorities for the COVID-19 pandemic: a call for action for mental health science. Lancet Psychiatry. 2020; 7 (6): 547 560. DOI: 10.1016/S2215-0366(20)30168-1

2. ВОЗ. Психическое здоровье и COVID-19 [WHO. Mental health and COVID-19]. URL: https://www.euro.who.int/ru/healthtopics/noncommunicable-diseases/mental-health/data-andresources/mental-health-and-covid-19

3. Wang C., Pan R., Wan X. et al. Immediate psychological responses and associated factors during the initial stage of the 2019 coronavirus disease (COVID-19) epidemic among the general population in China. Int J Environ Res Public Health. 2020: 17 (5). DOI: $10.3390 /$ ijerph17051729

4. Huang Y., Zhao N. Generalized anxiety disorder, depressive symptoms and sleep quality during COVID-19 outbreak in China: a web-based cross-sectional survey. Psychiatry Research. 2020; 288: 112954. DOI: 10.1016/j.psychres.2020.112954

5. Cellini N., Canale N., Mioni G. et al. Changes in sleep pattern, sense of time and digital media use during COVID-19 lockdown in Italy. $J$ of Sleep Research. 2020, e13074. DOI: $10.1111 /$ jsr. 13074

6. Odriozola-González P., Planchuelo-Gómez Á., Irurtia-Muñiz M.J. et al. Psychological symptoms of the outbreak of the COVID-19 crisis and confinement in the population of Spain, 2020. DOI: $10.31234 / \mathrm{osf} . \mathrm{io} / \mathrm{mq} 4 \mathrm{fg}$

7. Sonderskov K.M., Dinesen P.T., Santini Z.I. et al. The depressive state of Denmark during the COVID-19 pandemic. Acta Neuropsychiatr. 2020; 32 (4): 226-228. DOI: 10.1017/neu.2020.15

8. Ениколопов С.Н., Бойко О.М., Медведева Т.И. и др. Динамика психологических реакций на начальном этапе пандемии COVID-19. Психолого-педагогические исследования. 2020; 12 (2): 108-126. [Enikolopov S.N., Boyko O.M., Medvedeva T.I., etc. Dynamics of psychological reactions at the initial stage of the COVID-19 pandemic. Psychological and pedagogical research 2020; $12 \quad$ (2): 108-126.] (In Russ) DOI: 10.17759/psyedu.2020120207

9. Pancani L., Marinucci M., Aureli N. et al. Forced social isolation and mental health: A study on 1006 Italians under COVID-19 quarantine, 2020. DOI: 10.31234/osf.io/uacfj

10. Vindegaard N., Benros M.E. COVID-19 pandemic and mental health consequences: Systematic review of the current evidence. Brain Behav Immun. 2020. DOI: 10.1016/j.bbi.2020.05.048

11. Gunnell D., Appleby L., Arensman E. et al. Suicide risk and prevention during the COVID-19 pandemic. Lancet Psychiatry. 2020; 7 (6): 468-471. DOI: 10.1016/S2215-0366(20)30171-1

12. Stuckler D., Basu S., Suhrcke M. et al. The public health effect of economic crises and alternative policy responses in Europe: an empirical analysis. Lancet. 2009; 374 (9686): 315-323. DOI: 10.1016/S0140-6736(09)61124-7

13. de Berker A.O., Rutledge R.B., Mathys C. et al. Computations of uncertainty mediate acute stress responses in humans. Nat Commun. 2016; 7: 10996. DOI: 10.1038/ncomms 10996

14. Sher L. The impact of the COVID-19 pandemic on suicide rates. QJM, 2020, 113(10), 707-712. DOI: 10.1093/qjmed/hcaa202

15. Martin R.L., Smith N.S., McGrew S.J. et al. Aggressive Worriers: How Aggression Moderates the Association between Intolerance of Uncertainty and Suicidal Desire Constructs. Arch Suicide Res. 2019: 1: 20. DOI: 10.1080/13811118.2019.1689877

16. Zerach G., Levi-Belz Y. Intolerance of Uncertainty Moderates the Association Between Potentially Morally Injurious Events and Suicide Ideation and Behavior Among Combat Veterans. J Trauma Stress. 2019; 32 (3): 424-436. DOI: 10.1002/jts.22366

17. Demirtas A.S., Yildiz B. Hopelessness and perceived stress: the mediating role of cognitive flexibility and intolerance of uncertainty. Dusunen Adam The Journal of Psychiatry and Neurological Sciences. 2019; 32 (3): 259-267. DOI 10.14744/DAJPNS.2019.00035.

18. Zhang J. Теория суицидального напряжения. Сообщение I. Суииидология. 2020; 11 (2): 118-134. [Zhang J. The Strain Theory of Suicide. Part I. Suicidology. 2020; 11 (2): 118-134.] (In Russ) DOI: 10.32878/suiciderus.20-11-02(39)-118-134

19. Yao H., Chen J.H., Xu Y.F. Patients with mental health disorders in the COVID-19 epidemic. Lancet Psychiatry. 2020; 7 (4): e21. DOI: $10.1016 / \mathrm{S} 2215-0366(20) 30090-0$
20. Durkheim E. Le suicide; étude de sociologie. Paris: F. Alcan, 1897. XII, $462 \mathrm{p}$.

21. Calati R., Ferrari C., Brittner M. et al. Suicidal thoughts and behaviors and social isolation: A narrative review of the literature. $J$ Affect Disord. 2019; 245: 653-667. DOI: 10.1016/j.jad.2018.11.022

22. Stravynski A., Boyer R. Loneliness in relation to suicide ideation and parasuicide: a population-wide study. Suicide Life Threat Behav. 2001; 31 (1): 32-40. DOI: 10.1521/suli.31.1.32.21312

23. Hawkley L.C., Cacioppo J.T. Loneliness matters: a theoretical and empirical review of consequences and mechanisms. Ann Behav Med. 2010; 40 (2): 218-27. DOI: 10.1007/s12160-010-9210-8

24. Wasserman I.M. The impact of epidemic, war, prohibition and media on suicide: United States, 1910-1920. Suicide Life Threat Behav. 1992; 22 (2): 240-254

25. Yip P.S., Cheung Y.T., Chau P.H. et al. The impact of epidemic outbreak: the case of severe acute respiratory syndrome (SARS) and suicide among older adults in Hong Kong. Crisis. 2010; 31 (2): 86-92. DOI: 10.1027/0227-5910/a000015

26. Czeisler M.E., Lane R.I., Petrosky E. et al. Mental Health, Substance Use, and Suicidal Ideation During the COVID-19 Pandemic - United States, June 24-30, 2020. MMWR Morb Mortal Wkly Rep. 2020; 69 (32): 1049-1057. DOI: $10.15585 / \mathrm{mmwr} . \mathrm{mm} 6932 \mathrm{al}$

27. Dsouza D.D., Quadros S., Hyderabadwala Z.J. et al. Aggregated COVID-19 suicide incidences in India: Fear of COVID-19 infection is the prominent causative factor. Psychiatry Res. 2020; 290: 113145. DOI: 10.1016/j.psychres.2020.113145

28. Freeman L. Fight against fears. New York: Continuum, 1988. 352 $\mathrm{p}$.

29. Bauer R.L., Chesin M.S., Jeglic E.L. Depression, delinquency, and suicidal behaviors among college students. Crisis. 2014; 35 (1): $36-41$. DOI: $10.1027 / 0227-5910 / a 000226$

30. Нуллер Ю.Л., Михаленко И.Н. Аффективные психозы. Л.: М, 1988. 263 c. [Nuller Yu. L., Mikhalenko I. N. Affective psychoses. L.: M, 1988. 263 p.] (In Russ)

31. Mann J.J., Apter A., Bertolote J. et al. Suicide prevention strategies: a systematic review. JAMA. 2005; 294 (16): 2064-74. DOI: 10.1001/jama.294.16.2064

32. Derogatis L.R., Savitz K.L. The SCL-90-R and the Brief Symptom Inventory (BSI) in Primary Care. In: Maruish M.E. (Eds), Handbook of psychological assessment in primary care settings. Mahwah, NJ: Lawrence Erlbaum Associates, Publishers, 2000. P. 297-334.

33. Тарабрина Н.В. Практикум по психологии посттравматического стресса. СПб: Питер, 2001. 272 с. [Tarabrina N.V. Practicum on the psychology of post-traumatic stress. Saint Petersburg: Piter, 2001. 272 p.] (In Russ)

34. Carver C.S., Scheier M.F., Weintraub J.K. Assessing coping strategies: a theoretically based approach. Journal of Personality and Social Psychology. 1989; 56 (2): 267-83. DOI: 10.1037//0022-3514.56.2.267

35. Рассказова Е.И., Гордеева Т.О., Осин Е.Н. Копинг-стратегии в структуре деятельности и саморегуляции: психометрические характеристики и возможности применения методики СОРЕ. Психология. Журнал высшей школь экономики. 2013; 10 (1): 82-118. [Rasskazova E.I., Gordeeva T.O., Osin E.N. Coping strategies in the structure of activity and self-regulation: psychometric characteristics and possibilities of applying the COPE technique. Psychology. Journal of the higher school of Economics. 2013; 10 (1): 82-118.] (In Russ)

36. Vandoros S., Avendano M., Kawachi I. The association between economic uncertainty and suicide in the short-run. Social Science \& Medicine. 2019; 220: 403-410.

37. Казьмина О.Ю., Ениколопов С.Н., Медведева Т.И. и др. Прогноз суицида при депрессии. Вопросы психологии. 2015; 3: 38-48. [Kazmina O. Yu., Enikolopov S. N., Medvedeva T. I., etc. Prognosis of suicide in depression. Question of psychology. 2015; 3: 38-48.] (In Russ)

38. Шнейдман Э.С. Душа самоубийцы. М.: Смысл, 2001. 315 с. [Shneidman E. S. The soul of suicide. Moscow: Smysl, 2001. 315 p.] (In Russ)

39. Ronningstam E., Weinberg I., Goldblatt M. et al. Suicide and selfregulation in narcissistic personality disorder. Psychodynamic $\begin{array}{lllll}\text { Psychiatry. } & 2018 ; & 46 & \text { (4): } 491-510 . & \text { DOI: }\end{array}$ 10.1521/pdps.2018.46.4.491 


\title{
THE DYNAMICS OF DEPRESSIVE SYMPTOMS AND SUICIDAL IDEATION DURING THE COVID-19 PANDEMIC IN RUSSIA
}

\begin{abstract}
:
The COVID-19 pandemic may bear serious consequences for mental health, such as the increase in psychopathological symptoms, including suicidal ideation and autoaggressive actions. In our study, depressive symptoms and suicidality were viewed as two separate characteristics, which, during the pandemic, may be influenced by different factors. Study objective: analysis of the increase in depressive symptoms and suicidal ideation during the COVID-19 pandemic in Russia. Materials and methods. The materials for the study were the data from an anonymous internet survey, conducted during the period of March, 22 - June, 22, 2020. The survey included information on sociodemographic indicators and questions on how respondents assess their conditions during the pandemic; there was also a question on whether they were recently bothered by the thoughts of killing themselves. The following questionnaires were used: Symptom Check List 90-Revised (SCL-90-R) and the COPE Inventory. Statistical processing was performed with the SPSS program. Results: Nine hundred eight responses were received. The analysis showed a statistically significant positive correlation between the intensity of suicidal thoughts and severity of depressive symptoms according to the SCL-90-R (Spearman's coefficient $0.45 ; \mathrm{p}<0.001$ ). The analysis found a statistically significant growth trend in depressive symptoms as the pandemic progressed (Jonckheere - Terpstra test, Std. J-T stat. $=2.51, \mathrm{p}=$ 0.012), and the increase in frequency of suicidal thoughts that were expressed as 'strong' and 'very strong' in the last period of time (Fisher's Exact Test, 5.92, p = 0.046). The correlation analysis showed that the severity of depression is higher in women and younger respondents, and statistically significantly associated with the current situation of the pandemic: it is increased with the emergence of the virus in the city of residence, with the contraction of disease among friends, with increasing fears of getting sick and die, with the presence of various somatic diseases in respondents, and the number of methods used for protection from the infection. The intensity of suicidal ideation was not associated with the risk of contagion, with the presence of ill persons among the close others, with the fears for the self and close others, but was linked to the higher proneness to risk, was higher in males and younger respondents. Along with that, the severity of depressive symptoms was linked to the higher level of search for emotional, social and instrumental help as a coping strategy. With the growing frequency of suicidal thoughts, the acceptance and planning deteriorated. Conclusions: The increase in depressive symptoms and suicidal thoughts is determined by different factors. The increase in depressive symptoms is associated with various fears and mediated by non-constructive ways of coping with stress. But there are also constructive coping-strategies present, such as the search for help. The intensity of suicidal thoughts increases during the COVID-19 pandemic and is associated with the higher levels of stress, which cannot be explained by the 'objective' threat of contagion and fears for own life or lives of significant others, but is experienced as an 'indefinite' anxiety, supposedly linked to the measures to counter the pandemic, such as the restrictions on social interactions, loneliness, uncertainty. The increase in indices of depressive symptoms is linked with the orientation to another person, while the severity of suicidal ideation has no correlation with that.
\end{abstract}

Keywords: COVID-19, SARS-COV-2, depression, suicidal ideation, coping-strategies

Вкмад авторов:

Т.И. Медведева: формулировка концепции и структуры исследования, написание и редактирование текста статьи; C.Н. Ениколопов: написание и редактирование текста рукописи;

O.M. Бойко: анализ митературы, получение данных для анализа, статистическая обработка и анализ результатов исследования, написание текста статьи;

О.Ю. Воронцова: обзор публикаций по теме статьи, написание и редактирование текста рукописи;

Authors' contributions:

T.I. Medvedeva: formulation of the concept and structure of the study, article writing and correcting;

S.N. Enikolopov: article writing, article editing;

O.M. Boyko: reviewing relevant publications, empirical research, statistical data processing, article writing;

O.Yu. Vorontsova: reviewing of publications of the article's theme; article writing, article editing.

Финансирование: Исследование выполнено при поддержке гранта РФФИ 20-013-00129.

Financing: The study was supported by RFBR grant 20-013-00129.

Конфмикт интересов: Авторы заявцяют об отсутствии конфмикта интересов.

Conflict of interest: The authors declare no conflict of interest.

Статья поступима / Article received: 21.09.2020. Принята к публикации / Accepted for publication: 29.10.2020.

Для цитирования: Медведева Т.И., Ениколопов С.Н., Бойко О.М., Воронцова О.Ю. Анализ динамики депрессивной симптоматики и суицидальных идей во время пандемии COVID-19 в России. Суицидология. 2020; 11 (3): 316. doi.org/10.32878/suiciderus.20-11-03(40)-3-16

For citation: $\quad$ Medvedeva T.I., Enikolopov S.N., Boyko O.M., Vorontsova O.Yu. The dynamics of depressive symptoms and suicidal ideation during the COVID-19 pandemic in Russia. Suicidology. 2020; 11 (3): 3-16. (In Russ) doi.org/10.32878/suiciderus.20-11-03(40)-3-16 